\title{
An Ideological Construction of the Indigenous Community: The Orang Asli as Portrayed in The Star Newspaper
}

\author{
*MARLINA JAMAL \\ SHAKILA ABDUL MANAN \\ School of Humanities, Universiti Sains Malaysia, \\ 11800 USM Pulau Pinang, Malaysia \\ *Corresponding author: linasrk@yahoo.com
}

Published online: 30 December 2016

To cite this article: Marlina Jamal and Shakila Abdul Manan. 2016. An ideological construction of the indigenous community: The Orang Asli as portrayed in The Star newspaper. KEMANUSIAAN the Asian Journal of Humanities 23(Supp. 2): 39-62, https://doi.org/10.21315/kajh2016.23.s2.3

To link to this article: https://doi.org/10.21315/kajh2016.23.s2.3

\begin{abstract}
Powerful western nations, especially those which control global news media, tend to portray less powerful nations through a Western-centric lens or perspective in globalised space. As such, less powerful nations are depicted as weak and powerless victims, reinforcing in the process prevailing power structures or unequal relations between powerful nations and less powerful ones. Minority groups are also not spared as they are, more often than not, depicted in a similar negative way. Interestingly, this is where the global connects with the local as mainstream media in the local front are inclined to construct minority groups such as the Orang Asli or indigenous community through the lens or perspective of the powerful elite. They are not given the space to speak for themselves and as such portrayed as weak and disempowered. The indigenous people are often marginalised by the mainstream media because they in part do not constitute a constituency considered politically important; neither are they regarded crucial by profit-oriented media because they do not have the purchasing power which advertisers relentlessly seek via the media. Given this scenario, this study examines the portrayal of the Orang Asli in a mainstream paper, The Star newspaper, from a critical discourse analysis perspective. Utilising van Dijk's Theory of Semantic Macrostructures and Theory of Ideology, the projection of the community is inspected through the analysis of macro elements that is thematic structure and micro elements comprising lexical, syntactic and rhetorical structures. Findings reveal that the "self" group members comprising the ruling or powerful elite and governmental organisations were positively depicted while the Orang Asli were portrayed in a negative and stereotypical fashion. Needless to say, media coverage of indigenous people
\end{abstract}


globally has also often revolved around similar stereotypical images that are both pejorative and discriminatory.

Keywords and phrases: global news media, critical discourse analysis, semantic macrostructures, ideology, Orang Asli

\section{Introduction}

Nations with advanced technology arguably wield greater political power as they are in a position to control the flow of information and the circulation of international images globally. Backed by power, they actively participate in global dialogue excluding in the process views and the interests of less powerful nations. Bereft of power, less powerful nations are not given the opportunity to speak for themselves, instead they are produced to the world through a Westerncentric lens or perspective. As such, they are normally constructed as weak and powerless victims and denied agency, which helps to sustain prevailing power structures or hegemonic relations between Western powerful nations and less powerful ones in global space (Owen in Brown 2003, 237).

On the local front, a similar scenario exists as the mainstream media, those owned by the powerful elite, tend to exclude or belittle the views and interests of minority groups such as the Orang Asli or indigenous community, often speaking for them instead of allowing them the space to speak for themselves. Portrayed as weak, backward and disempowered victims, they tend to be excluded from participating in national dialogues and from decision-making spheres in their very own countries (Inguanzo 2011). This is not surprising as Meadows (2001) argues that the media coverage of indigenous people globally has often revolved around stereotypical images that have been overtly discriminatory.

The indigenous people are often marginalised by the mainstream media because they in part do not constitute a constituency considered politically important; neither are they regarded crucial by profit-making media because they do not have the purchasing power which advertisers relentlessly seek via the media. Even if these marginalised people are indeed covered occasionally by the mainstream media, very often they are depicted in a patronising, if not derogatory, fashion. As such, the national media, which are driven by market forces, in many ways only reinforce the common discursive practices of global media. 
Media representation has the capability to affect the perceptions of diverse groups as negative portrayals promote negative attitudes while positive portrayals encourage positive attitudes. In simple terms, common forms of the mass media such as the newspapers, radio channels and television broadcasts act as key players in influencing public opinion about minorities (van Dijk 2000). In this context, a news article is particularly essential due to the social function it conveys, which is the reconstruction of reality for the people who were not present at the site of a news event (Schlesinger 1998). The portrayal of the aborigines by the media (of which this study concerns) has seen no change, as for decades, the indigenous peoples have been portrayed in a pejorative and discriminatory fashion.

This paper seeks to explore the negative portrayal of the community as communicated in mainstream media. A thorough search revealed that only a limited number of studies have been conducted on the portrayal of the Orang Asli in major Malaysian newspapers such as the research carried out by David, Ponmalar and Sri Kumar (2010) and Loh (2001). However, these studies did not perform a linguistic analysis of the news reports in order to reveal the ideology that is being proffered. Instead they focused only on broad themes drawn from news reports on the Orang Asli and tags that are attached to the Orang Asli through textual analysis. Zawawi Ibrahim (1996) asserts the necessity for more research on the Orang Asli in order to contest the hegemony of the dominant discourses in the mainstream media pertaining to the Orang Asli.

\section{Research Objectives}

In order to effectively analyse the strategies used to depict minorities in the media, discourse analysts such as van Dijk (2001) suggest a method of critical analysis which involves scrutinising the macro and micro features of a certain text. Through the application of this method, the objectives stated as follows are hoped to be addressed:

1. To determine the semantic macrostructures (thematic structures) of the selected news reports on the Orang Asli.

2. To determine the semantic microstructures (lexical choice, syntactic style and rhetorical patterns) of the selected news reports on the Orang Asli.

3. To reveal the ideology that is being reinforced through the use of these linguistic features. 


\section{Situating the Orang Asli}

\section{The Orang Asli as people}

The Orang Asli expression refers to the indigenous minorities residing in Peninsular Malaysia. They are commonly known as the early descendants or inhabitants of the peninsula before the establishment of the Malay Kingdoms. The Orang Asli community comprises approximately 150,000 people-representing less than $1 \%$ of the total population of Malaysia. The term Orang Asli which literally translates to "Original People" is the official name for the people of the indigenous minorities in Peninsular Malaysia (Lye 2011). Socio-economically, the Orang Asli today are regarded as the most impoverished community (Nicholas et al. 2000). In statistics provided in the Government's 10th Malaysia Plan (2011-2015), almost 50\% of the 29,990 Orang Asli households in existence live below the poverty line while $19 \%(5,700)$ of the same households are deemed to be in the hard core poor category. Their level of poverty is usually manifested in the absence of basic amenities and infrastructure in their large villages. Although improvements have been made in the provision of amenities in recent years, the Orang Asli still lag behind the rest of the other communities in Malaysia in terms of access to basic infrastructure and this includes access to electricity, potable water and proper roads.

Based on news reports, the general perception is that they are lacking in direction and are dependent on the government's largesse. This perception has been formed as the government's policy of "integrating the Orang Asli into the mainstream community" implies that they need to be governed or administered as they are incapable of managing their own lives (Sabihah 1997). Such executive administration over the Orang Asli is carried out through the Department of Orang Asli Affairs (Jabatan Hal-Ehwal Orang Asli [JHEOA]), a government agency that is entrusted the responsibility of looking after Orang Asli affairs and development.

\section{Historical context of the Orang Asli}

The Orang Asli were the first peoples on this peninsula and actively participated in the political and economic structure of early civilisation (Nicholas et al. 2000). Nonetheless, with the influx of immigrant people (namely the British and the Japanese) who coveted the Orang Asli resources, perceived their usefulness and dealt with them accordingly. Thus, they were reduced to mere salvagers and wards of the sultans by the time of British colonialism (Howell 1995). 
Inhabitants of the Malay Peninsula had gradually converted to Islam since the rise of the Melaka Sultanate in the 15th century. This process of Islamisation had at times involved the colonisation of the inland regions, with rampant looting and also slavery. This scenario had called for a re-evaluation of the relationship between the (mostly non-Muslim) indigenous people and the migrants. NonMuslims were forced to become slaves as the Islamic law prohibits Muslims from keeping other Muslims as slaves (Dentan et al. 1997; Roseman 1984). The Orang $A s l i$, who were then treated as infidels or non-believers of the Islamic faith (kafir) became targets for exploitation and slavery. Reports by various authors such as Swettenham (1880), Clifford (1897) and Wray (1903) provide evidence that the Orang Asli were treated as if they were wild animals and were subjected to pillage and slavery. Under British colonisation, Malays were given Malay reservations while the Orang Asli were confined to Sakai reservations. By the year 1913, the Malays had been given rights to own and lease property, but the same privilege had been denied to the Orang Asli.

\section{Islamising the Orang Asli}

The intensity of the Islamisation policies in relation to the Orang Asli had gradually increased since the 1980s. Carey (1970) and Baharon Azhar Raffie'i's (1968) discussion of the issue of Islamisation among the Orang Asli community highlight the relatively small number of Muslims among them. The Malaysian government also requested that JHEOA promote Islamic missionary activities among the Orang Asli. JHEOA had tried to provide Islamic converts with housing (including water and electricity supplies), income-earning opportunities, education, health and transportation facilities that were better than those supplied to the non-Muslims. By the same token, considerable preferences were given to Muslim Orang Asli employees in job promotion decisions and it was generally believed that a non-Muslim could not rise to the upper ranks in the JHEOA (Dentan et al. 1997). This "positive discrimination" policy which endorsed affirmative action for the Islamic converts among the Orang Asli, caused a negative effect on the community as a whole. The policy makers might have thought that the Orang Asli would choose to be converted to Islam in order to obtain various kinds of governmental assistance.

\section{The Orang Asli today}

While the Orang Asli fulfil the internationally-accepted criteria and principles that structure the "definition" of indigenous people and are also near perfect claimants to the rights and entitlements that come with such recognition, however they are not granted the proper recognition in Malaysia. Paradoxically, it is the Malay community which enjoys the rights and protections enshrined in the United Nations Declaration on the Rights of Indigenous Peoples (UNDRIP) as 
compared to the Orang Asli, even though the Malay community do not identify themselves as indigenous people (Bowen 2000). The discrimination faced by the Orang Asli is apparent in the programmes and policies designed and constructed for them. Ironically, many people who do not belong to this ethnic group claim all these benefits that were meant originally for the Orang Asli (Nicholas et al. 2000). In addition, the disparity in protections also extends to more materialistic aspects of the Orang Asli's concerns, especially the security of tenure of their traditional lands (Rachagan 1990).

It is only fair that the Orang Asli be accorded proper recognition as mentioned in the UNDRIP. In a broader sense, the non-recognition of the Orang Asli as indigenous people is most probably the root cause of all things negative that are happening to them and their territories. These include a complete absence of their participation in decision-making processes, the selection of their leaders by others, declining cultural integrity, heightened prejudice against them, an apparent insufficiency of basic infrastructure and the increasing degradation of their environments (Nicholas et al. 2000).

\section{Review of Related Studies}

It is observed that in terms of research, there has been a shift from a traditional ethnographical discussion of the Orang Asli to other issues such as the effect of development projects and policies, political representation, indigenous rights and also the negative portrayal of the Orang Asli in the media both in the local and also global context (Nicholas et al. 2000). David et al. (2010) in their study confirmed that the Orang Asli has not only been marginalised but is also portrayed in a negative way in the local news media and Loh (2011) found that the Orang Asli had been side-lined when it came to reporting about them in the mainstream media, especially in The Star newspaper.

Besides the discriminatory representation of the Orang Asli in the media, studies have concluded that the other minorities have also been depicted in a biased way. Maslin (2002) examined the portrayal of Canadian Aborigines in the country's two daily newspapers, the Leader Post and the Star Phoenix and revealed that the negative and stereotypical messages about the indigenous people that appeared in the newspapers served to reinforce and reproduce a racist ideology and a negative representation. Taylor (2005) had focused on the cultural and political representations of the European indigenous people, Sami and reported that they are under-represented in almost all major media as well and even if portrayal does happen, it tends to be negative. Dunn and Mahtani (2001) examined the media representations of certain ethno-cultural groups in Australia and Canada and found that there were inclinations towards under-representation and mis- 
representations of these groups of people. They also revealed that ethnic minorities were largely absent from media coverage prior to 1990 . The previous research had helped to inform this current study as the researcher aims to investigate if similar depictions of Orang Asli occur in selected news reports in The Star newspaper.

\section{Theoretical Framework}

This study utilises two main theories in the hope of extracting a coherent and detailed analysis of the news reports. The selected theories include van Dijk's Theory of Semantic Macrostructures and van Dijk's Theory of Ideology. Before discussing the theories, it is pertinent to first explain the aims of critical discourse analysis.

\section{Critical discourse analysis}

Critical discourse analysis (CDA) is a field in which emphasis is placed on studying and analysing written and spoken texts to reveal the discursive sources of power, dominance, inequality and bias (van Dijk 1998). It explores the relationship between structures and strategies of text on the one hand and social, political and cultural structures and processes on the other. CDA is aware of the fact that texts are not only a result of social and political contexts, but also have the constitutive power to shape cognition and influence relations among various social groups (van Dijk 1998; Fairclough 1995). The central concern of CDA, therefore, is how the structures of discourse reflect, confirm, legitimise, reproduce or challenge power relations in society (Fairclough 1995).

\section{van Dijk's Theory of Semantic Macrostrucures}

According to van Dijk (1980), macrostructures refer to higher level semantics or conceptual structures which organise the local microstructures of a particular discourse. They are used to account for the various concepts of global meanings, such as theme, gist and topic. They also help to compress complex information into themes and only feature the most prominent, general and relevant data from aforementioned complex units of information. Thus, macrostructures allow for a more comprehensive understanding of complex information. Thematic analysis, one of the rubrics under macrostructures, refers to the process of organising themes in providing an overall picture of a discourse.

The analysis of microstructures focuses on lexical structures, syntactic structures and also rhetorical features. Lexical structures deal with the choice of words used in the reporting of a news event. Goatly $(2000,8-9)$ contends that the choice of 
vocabulary reflects an author's ideological point of view. For example, there is a difference when the word "rebel" is chosen over "freedom fighter" to refer to actors who resist an oppressive government or ruling party. The choice made will also cast unnecessary aspersions on the actors that are being referred to. In the analysis of lexical items, attention is paid to different word classes and the quality they carry; nouns signify the category of things, verbs symbolise temporary qualities while adjectives project permanent qualities (Goatly, 2000).

Syntactic analysis looks at elements suggested by Biber and Conrad (2004) such as complexity of sentences, selection of tenses and also type of sentences. In the analysis on rhetorical structures, attention is paid to figures of discourse which include series, testimonies, understatements, hyperboles and repetitions which all play their respective roles in encoding certain meanings and ideologies.

\section{van Dijk's theory of ideology}

According to van Dijk (1998), ideology is both social and cognitive and refers to the basic backbone in organising the social cognition shared by members of a particular social group, organisation or institution. Ideologies are acquired by the members of a social group and represent the characteristics of their group in terms of their identity, values and norms practiced.

Central to the investigation of language and ideology are two important constructs that is "self" and the "other". According to Stevens (1998) and Duncan (1996), the concept of the "self" and the "other" can be traced as far back in time to Plato who used it to describe the relationship between an observer (the "self") and an observed (the "other"). In modern social science, the term "external other" or the "social other" is commonly used to refer to all people the "self" perceives as different (Bakhtin 1981). The "other" is often perceived as a homogeneous category except for those few individuals who are known personally. On the other hand, the "self" tends to make finer distinctions between its own members. The concept of "self" (us) vs the "other" (them) is strategically employed in discriminatory discourses where positive things about the "self" will be emphasised while positive traits relating to the "other" will be downplayed. In the same vein, negative traits about the "self" will be dismissed while negative traits about the "other" will be given prominence. In this paper, the "self" refers to the powerful or ruling party of the country, governmental associations and authoritative figures such as law enforcers, while the "other" refers to the Orang Asli community. 
The subsequent figure summarises the theoretical framework of this study. The analytical process begins with a linguistic evaluation while the theory of ideology is incorporated to determine the ideological representation of the actors involved in the news reports.

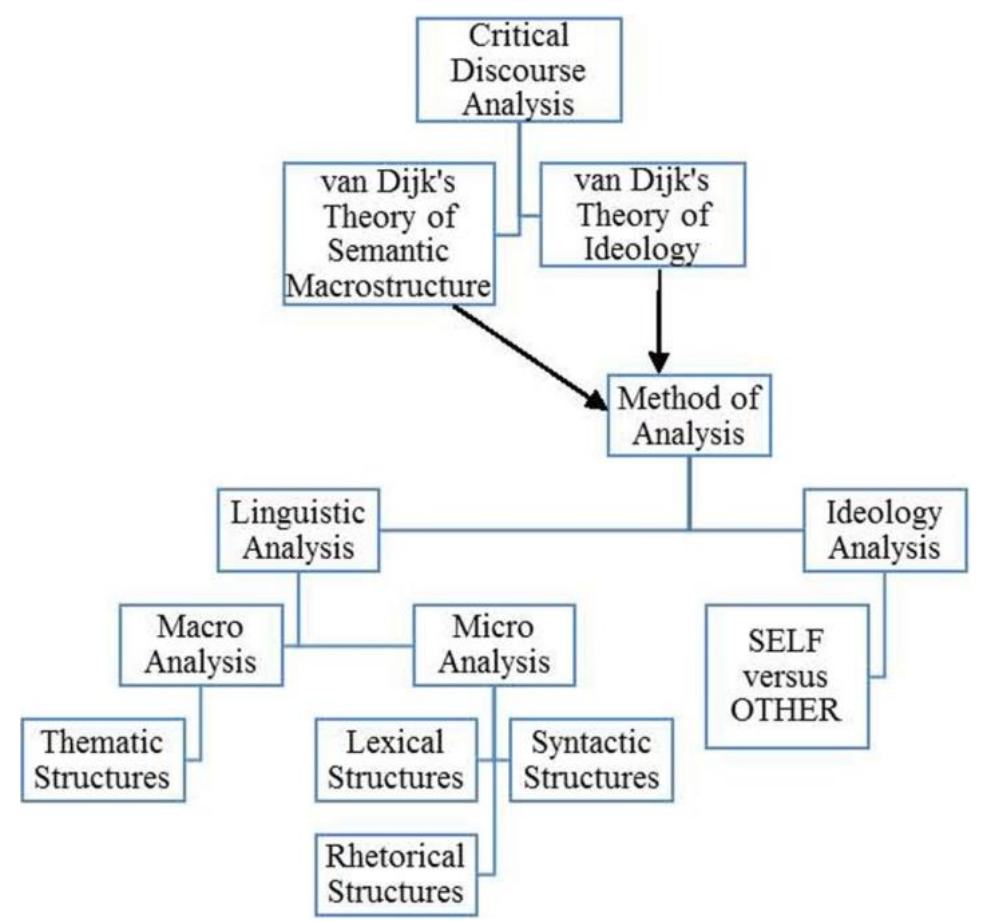

Figure 1. Theoretical framework

\section{Methodology}

The aim of this study is to analyse the portrayal of the Orang Asli community by examining 12 different news reports previously published in The Star newspaper. This local daily was selected for two reasons. Firstly, a thorough search revealed that, to date, no studies have analysed the depiction of the Orang Asli in The Star newspaper. However, there was one study which examined news reports on the Orang Asli in the New Straits Times (another mainstream daily), while the other study compared the depictions of the Orang Asli in The Star and the Malaysian Insider (an online news portal). Secondly, The Star recorded having had a higher coverage of events and incidents that are related to the Orang Asli community in contrast to other local newspapers (Loh 2011). This study incorporates van Dijk's Theory of Semantic Macrostructures to analyse the macro and micro-level structures of the news reports and van Dijk's Theory of Ideology in studying the discursive polarisation of the "self" versus the "other". 


\section{Corpus}

The corpus of this study consists of 12 news articles extracted from The Star published between 6 March 2011 and 12 October 2011. The selection of the news reports was based on their relevance to the purpose of this research which is to identify the portrayal of the Orang Asli community in the news reports. The articles were coded S1 to S12.

\section{Data Analysis Procedure}

The next table presents the data analysis procedure. Every individual text will be inspected on three different levels of analysis: macro analysis, micro analysis and ideological analysis.

Table 1. Data analysis procedure

\begin{tabular}{cll}
\hline Step & Theory & Type of analysis \\
\hline 1 & Macro analysis & $\begin{array}{l}\text { Analysis of thematic structures } \\
\text { Analysis of lexical structures (verbs, adjectives, positive and } \\
\text { negative registers, words that reinforce stereotypes) }\end{array}$ \\
3 & Micro analysis & $\begin{array}{l}\text { Analysis of syntactic structures (present tense, past tense, clauses, } \\
\text { declarative sentences) } \\
\text { Analysis of rhetorical structures (series, testimonies, } \\
\text { dysphemisms, repetition, understatement, hyperbole) } \\
4\end{array}$ \\
5 & & Analysis of ideology \\
\hline
\end{tabular}

\section{Discussion}

This section reports and discusses the findings of the data analysis.

\section{Analysis of semantic macrostructures (thematic structures)}

Semantic macrostructures derived from the analysis of the 12 articles are presented in the following table: 
Table 2. Semantic macrostructures of the data

\begin{tabular}{|c|c|}
\hline News reports & Semantic macrostructures \\
\hline S1 & $\begin{array}{l}\text { Jabatan Kemajuan Orang Asli (JAKOA) wants to help the Orang Asli } \\
\text { community who are in need of aid. }\end{array}$ \\
\hline S2 & $\begin{array}{l}\text { The Orang Asli community is contented with the changes brought by } \\
\text { Barisan Nasional leaders. }\end{array}$ \\
\hline S3 & $\begin{array}{l}\text { National Key Results Area (NKRA) has improved the performance of } \\
\text { students. }\end{array}$ \\
\hline S4 & $\begin{array}{l}\text { Many Orang Asli individuals are attached to the government sector and } \\
\text { living better lives. }\end{array}$ \\
\hline S5 & $\begin{array}{l}\text { A recent landslide has prompted an emergency fund to be set up for the } \\
\text { Orang Asli. }\end{array}$ \\
\hline S6 & $\begin{array}{l}\text { The Orang Asli is unhappy over JAKOA's finalisation on land policy and } \\
\text { have lodged complaints with the Bar Council. }\end{array}$ \\
\hline S7 & $\begin{array}{l}\text { Declining forest resources are troubling the Orang Asli who still depend } \\
\text { on forests for survival. }\end{array}$ \\
\hline S8 & $\begin{array}{l}\text { 5,400 Orang Asli did not register their birth due to negligence and } \\
\text { distance constraints. }\end{array}$ \\
\hline S9 & $\begin{array}{l}\text { The Oracle employees raised RM 5,000 to purchase basic food items and } \\
\text { donated them to several Orang Asli settlements. }\end{array}$ \\
\hline S10 & $\begin{array}{l}\text { The government is helping the Orang Asli community, but to live a better } \\
\text { life, they have to change their attitude and lifestyle. }\end{array}$ \\
\hline S11 & $\begin{array}{l}\text { The Orang Asli staged a peaceful protest claiming a company has taken } \\
\text { their land. }\end{array}$ \\
\hline S12 & $\begin{array}{l}\text { Hulu Selangor Member of Parliament (MP) is determined to curb the } \\
\text { Orang Asli, both adults and children's drinking habit by implementing } \\
\text { better measures. }\end{array}$ \\
\hline
\end{tabular}

An analysis of the semantic macrostructures reveals the following broad themes: social issues, corporate social responsibility, poor economic conditions and politics. Politics is a recurring theme as several news reports involving the community are often politicised to favour the ruling party that is members of the "self" community. Out of the 12 news reports analysed, the "self" is positively portrayed for a total of nine times while the Orang Asli are positively presented once and neutrally twice. Often, the theme of the news reports focuses on the altruism of the ruling party and its efforts to develop the community. The broad themes are explicated as follows. 


\section{JAKOA is continuously aiding the Orang Asli community without fail}

JAKOA (Department of Orang Asli Development) is a government department which is solely responsible for looking after the welfare of the community and in the news reports analysed, multiple references to the organisation are made both in the semantic macrostructures and also in the specific lines of the news reports. In news report S1, the semantic macrostructure derived is "JAKOA wants to help the Orang Asli community who are in need of aid". This obviously provides a positive portrayal of the government department.

JAKOA is mentioned again in news report S6. In this report, the semantic macrostructure reads "The Orang Asli is unhappy over JAKOA's finalisation on land policy and have lodged complaints with the Bar Council". In this context, the department is portrayed as the drafters of the land policy for the community. However, the community is negatively portrayed as they are shown to have rejected it. They also lodged a complain with the Bar Council. Reasons for the rejection are not given.

\section{Barisan Nasional are bringing significant changes to the Orang Asli community}

Another recurring theme is the positive projection of the ruling Barisan Nasional government as saviours of the community. Since the identification of the actors is necessary in order to highlight their positive deeds, the news reports reveal the identity of the many governmental organisations who went to the aid of the community by providing basic necessities, setting up a fund and assisting the Orang Asli children in terms of educational progress.

\section{The Orang Asli community is an ignorant community which is always in need of help}

Another persistent theme is the depiction of the Orang Asli as negligent, dependent, backward and potentially violent. Their negligence was exposed through their failure to register their births while their backwardness was shown through their reluctance to embrace modernity in order to improve their lifestyle. This was evident in the semantic macrostructure of news report S1 (JAKOA wants to help the Orang Asli community who are in need of aid) and S7 (5,400 Orang Asli did not register their births due to negligence and distance constraints). The projection of the community as potentially violent was shown when they are depicted as protestors. This can be observed especially in semantic macrostructure S6 (The Orang Asli is unhappy over JAKOA's finalisation on land policy and have lodged complaints with the Bar Council) and S11 (The Orang Asli staged a peaceful protest claiming a company has taken their land). 
This reinforces the findings of Wilson II and Gutierrez (1995) who said that minorities tend to be demeaned in the media through the use of several repetitive and stereotypical traits such as being dependant and traditional. Another dimension in the way the Orang Asli was portrayed is by excluding them from the decision-making process, especially when crucial policies are being drafted. Inguanzo (2011) contends that minorities are excluded when important decisions about them are being made. A similar scenario is observed in news report S6 when the community expresses its dissatisfaction towards the implementation of a land policy by JAKOA.

In sum, the semantic macrostructures play a vital role as they help to extract the main themes of the news reports that were analysed. The analysis of the semantic macrostructures closely follows the procedures carried out by van Dijk (1988; 1991) in terms of inspecting and scrutinising news reports to look for stereotypes and discriminations.

\section{Analysis of Semantic Microstructures}

The discussion will be divided into three subsections to depict the three levels of analysis, namely the lexical, syntactic and rhetorical analysis.

\section{Lexical analysis}

The different frequencies of lexical items extracted from the 12 news reports will be presented in the table.

Table 3. Types of lexical items found and their frequency

\begin{tabular}{lll}
\hline $\begin{array}{l}\text { Lexical } \\
\text { structures }\end{array}$ & $\begin{array}{l}\text { Examples from the } \\
\text { news reports }\end{array}$ & Explanation \\
\hline $\begin{array}{l}\text { Dynamic verbs } \\
(6 \times)\end{array}$ & $\begin{array}{l}\text { 1....number showed that } \\
\text { the standard of living of the }\end{array}$ & $\begin{array}{l}\text { In Example 1, the verb "improved" has been } \\
\text { used to refer to the positive change in the } \\
\text { condition of the Orang Asli community }\end{array}$ \\
$\begin{array}{l}\text { (verbs that show } \\
\text { qualities that are } \\
\text { capable of } \\
\text { change) }\end{array}$ & $\begin{array}{l}\text { Orang Asli in the country } \\
\text { has improved... }\end{array}$ & \\
\hline
\end{tabular}


Table 3. (Continued)

\begin{tabular}{|c|c|c|}
\hline $\begin{array}{l}\text { Lexical } \\
\text { structures }\end{array}$ & $\begin{array}{l}\text { Examples from the } \\
\text { news reports }\end{array}$ & Explanation \\
\hline $\begin{array}{l}\text { Stative verbs }(3 \times) \\
\text { (verbs that refer to } \\
\text { inert perception } \\
\text { and cognition) }\end{array}$ & $\begin{array}{l}\text { 1. He said the Orang Asli } \\
\text { were now able to enjoy } \\
\text { better livelihood... }\end{array}$ & $\begin{array}{l}\text { The stative verb "enjoy" is employed to } \\
\text { describe the state of the community. They } \\
\text { are shown to be joyful as there is some } \\
\text { improvement in their livelihood. }\end{array}$ \\
\hline $\begin{array}{l}\text { Attributive } \\
\text { adjective }(11 \times) \\
\text { (adjective which } \\
\text { is placed before a } \\
\text { noun) }\end{array}$ & $\begin{array}{l}\text { 1. A special emergency } \\
\text { fund will be set up by the } \\
\text { Peninsular Malaysia } \\
\text { Orang Asli Association } \\
\text { (POASM)... } \\
\text { 2. With the fund, we can } \\
\text { channel immediate } \\
\text { financial assistance to the } \\
\text { Orang Asli community... } \\
\text { 3. We have qualified } \\
\text { engineers and geologists } \\
\text { who would be able to give } \\
\text { their expert opinion. }\end{array}$ & $\begin{array}{l}\text { Attributive adjectives have been extensively } \\
\text { used in the news reports. In Sentence } 1 \text {, the } \\
\text { adjective "special" is used to refer to the } \\
\text { extraordinary fund that has been set up for } \\
\text { the Orang Asli. It shows that steps have } \\
\text { been taken to help the Orang Asli cope with } \\
\text { emergency situations. As for Sentence 2, } \\
\text { the term "immediate" further exemplify the } \\
\text { instantaneous help that may be given to the } \\
\text { community. In Example } 3 \text {, the president of } \\
\text { POASM asserts that there are experts } \\
\text { among the Orang Asli community which } \\
\text { are indicated by the adjectives "qualified" } \\
\text { and "expert". }\end{array}$ \\
\hline $\begin{array}{l}\text { Predicative } \\
\text { adjective }(7 \times) \\
\text { (adjectives which } \\
\text { occur in subject } \\
\text { predicative } \\
\text { position) }\end{array}$ & $\begin{array}{l}\text { 1. The Orang Asli of } \\
\text { Belum-Temenggor are } \\
\text { still very dependent on the } \\
\text { forest for their existence. } \\
\text { 2. ...the Orang Asli were } \\
\text { intelligent but led a low- } \\
\text { profile life and were lost in } \\
\text { the mainstream of } \\
\text { development.... }\end{array}$ & $\begin{array}{l}\text { Predicative adjectives have been used in } \\
\text { two ways, to positively and negatively } \\
\text { describe the "other". Many predicative } \\
\text { adjectives such as "lost", "dependent", } \\
\text { "low-profile" and "left out" were used to } \\
\text { describe the Orang Asli community. Some } \\
\text { positive ideas such as describing the Orang } \\
\text { Asli as "humble" and "intelligent" are also } \\
\text { employed. }\end{array}$ \\
\hline $\begin{array}{l}\text { Negative registers } \\
(13 \times)\end{array}$ & $\begin{array}{l}\text { 1. These days they come in } \\
\text { asking for Golden Axe and } \\
\text { Myami - which are cheap } \\
\text { whisky with high alcohol } \\
\text { content. }\end{array}$ & $\begin{array}{l}\text { A proliferation of lexical items relating to } \\
\text { alcohol are also found in the news reports. } \\
\text { These include words such as "cheap } \\
\text { whisky", "hard liquor", "cheap liquor" and } \\
\text { "dark brew" to inform the readers on the } \\
\text { drinking culture of the community. }\end{array}$ \\
\hline
\end{tabular}


Table 3. (Continued)

\begin{tabular}{|c|c|c|}
\hline $\begin{array}{l}\text { Lexical } \\
\text { structures }\end{array}$ & $\begin{array}{l}\text { Examples from the } \\
\text { news reports }\end{array}$ & Explanation \\
\hline \multirow{4}{*}{$\begin{array}{l}\text { Words that help to } \\
\text { stereotype the } \\
\text { community }(5 x)\end{array}$} & $\begin{array}{l}\text { 1. Living in remote areas in } \\
\text { Pahang ... }\end{array}$ & \multirow{4}{*}{$\begin{array}{l}\text { The community is described as having } \\
\text { low living standards, failing to keep up } \\
\text { with development, living in remote areas, } \\
\text { refusing to change their attitude and } \\
\text { finally relying on the forest for survival. }\end{array}$} \\
\hline & $\begin{array}{l}\text { 2. ... Orang Asli were } \\
\text { intelligent but led a low- } \\
\text { profile life and were lost in } \\
\text { the mainstream of } \\
\text { development. }\end{array}$ & \\
\hline & $\begin{array}{l}\text { 3. ...to change their attitude } \\
\text { and lifestyle. }\end{array}$ & \\
\hline & $\begin{array}{l}\text { 4. ...they could earn a fixed } \\
\text { income apart from } \\
\text { participating in their usual } \\
\text { chores like hunting and } \\
\text { foraging in the forest and } \\
\text { doing odd jobs... }\end{array}$ & \\
\hline \multirow{2}{*}{$\begin{array}{l}\text { Phrasal verb }(4 \times) \\
\text { (a phrase } \\
\text { consisting of a } \\
\text { noun and } \\
\text { preposition) }\end{array}$} & $\begin{array}{l}\text { 1. Hulu Selangor's Orang Asli } \\
\text { community is in danger of } \\
\text { being hooked on compounded } \\
\text { hard liquor. }\end{array}$ & \multirow{2}{*}{$\begin{array}{l}\text { Phrasal verbs such as "hooked on", "get } \\
\text { rid of" have been used in the report to } \\
\text { project the alcohol addiction issue among } \\
\text { the community and also the } \\
\text { determination of an MP to help alleviate } \\
\text { the problem. }\end{array}$} \\
\hline & $\begin{array}{l}\text { 2. ...has an unsavoury } \\
\text { reputation that Hulu Selangor } \\
\text { MP P. Kamalanatan is } \\
\text { determined to get rid off... }\end{array}$ & \\
\hline
\end{tabular}

With reference to Table 3, the lexical items used help to depict the Orang Asli as a people with certain negative traits and behaviour. These words tend to further reinforce stereotypes about the Orang Asli. For instance, they are shown to reject modernity and progress and have imbibed a serious drinking culture. In contrast, the government is positively portrayed as they are shown to bring progress and development to the community through government projects.

Evidently, the news reports reveal an ideological slant. As van Dijk (1988) posits, the use of lexical items will normally favour the "self" group members by accentuating their positive representation and the negative representation of the "other". The findings of the lexical analysis concur with David et al. (2010) who argued that the Orang Asli are often portrayed in a negative manner in the media.

\section{Syntactic Analysis}

The following table presents the different types and the frequency of syntactic elements discovered during the analysis. 
Table 4. Types of syntactic items found and their frequency

\begin{tabular}{|c|c|c|}
\hline $\begin{array}{c}\text { Syntactic structures } \\
\times \text { frequency }\end{array}$ & Examples from text & Explanation \\
\hline Present tense $(11 \times)$ & $\begin{array}{l}\text { 1. Living in remote areas in Pahang } \\
\text { is one of the reasons why Orang } \\
\text { Asli groups don't enjoy good living } \\
\text { standards compared to other } \\
\text { communities. } \\
\text { 2. This is a good development } \\
\text { because... } \\
\text { 3....they are now with us in the } \\
\text { mainstream... }\end{array}$ & $\begin{array}{l}\text { The most common type of tense } \\
\text { used in the news reports. It } \\
\text { depicts facts and truths. Simple } \\
\text { present tense is used to depict } \\
\text { the state of the Orang Asli as } \\
\text { being dependent on the forest. } \\
\text { And that they lived in remote } \\
\text { areas. }\end{array}$ \\
\hline Past tense $(8 \times)$ & $\begin{array}{l}\text { 1. "The water came back after all } \\
\text { these leaders came", said rubber } \\
\text { tapper Ismail Yusuf. } \\
\text { 2. Villager Muhamad Lasim, } 34 \text {, } \\
\text { said many of them had applied for } \\
\text { land in nearby areas but not all of } \\
\text { them had been successful. }\end{array}$ & $\begin{array}{l}\text { Simple past tense is used to } \\
\text { illustrate the many projects } \\
\text { implemented by the government } \\
\text { for the community. }\end{array}$ \\
\hline $\begin{array}{l}\text { To-clause }(7 \times) \\
\text { (clause that serves } \\
\text { as the direct object } \\
\text { of the verb) }\end{array}$ & $\begin{array}{l}\text { 1. A special emergency fund will be } \\
\text { set up by the Peninsular Malaysia } \\
\text { Orang Asli Association (POASM) } \\
\text { to help the community when natural } \\
\text { disasters strike. } \\
\text { 2. Earlier, Mohd Shafie attended a } \\
\text { meeting to discuss Orang Asli and } \\
\text { issues at Wisma Darul Iman here. }\end{array}$ & $\begin{array}{l}\text { The to-clause is the most } \\
\text { common syntactic structure used } \\
\text { in the news reports. It functions } \\
\text { to provide elaboration on actions } \\
\text { taken by both the "self" and the } \\
\text { "other" group members. In this } \\
\text { regard, positive deeds by the } \\
\text { ruling party are elaborated using } \\
\text { the to-clause. }\end{array}$ \\
\hline $\begin{array}{l}\text { Declarative } \\
\text { sentences }(16 \times) \\
\text { (sentences which } \\
\text { provide } \\
\text { information) }\end{array}$ & $\begin{array}{l}\text { 1. The items included rice, } \\
\text { condensed milk, cooking oil and } \\
\text { other daily provisions. } \\
\text { 2. Similar provisions were also } \\
\text { delivered to the Gabai and Pangsun } \\
\text { Orang Asli settlements. } \\
\text { 3. The Orang Asli of Belum- } \\
\text { Temenggor are still very dependent } \\
\text { on the forest for their existence. }\end{array}$ & $\begin{array}{l}\text { Employed for a total of } 16 \text { times, } \\
\text { declarative sentences help to } \\
\text { deliver information on the } \\
\text { impoverished condition of the } \\
\text { Orang Asli and their primitive or } \\
\text { traditional lifestyle. }\end{array}$ \\
\hline
\end{tabular}

The syntactic analysis focuses on the ways words are organised in sentences. It targets elements such as the types of sentences and also the selection of tenses. Tenses for instance, indicate time dimension and news reports may be assumed to be very sensitive to time factor. In the analysis, past form is used in reporting past events about the Orang Asli community and these include the successful implementation of government projects. Present tense which functions to provide 
general truths is used to report on the improved socio-economic condition of the Orang Asli.

\section{Rhetorical Analysis}

Table 5 summarises the types and the frequency of different rhetorical structures located in all the news reports.

Table 5. Types of rhetorical items found and their frequency

\begin{tabular}{|c|c|c|}
\hline $\begin{array}{l}\text { Rhetorical structures } \\
\times \text { frequency }\end{array}$ & Examples from text & Explanation \\
\hline $\begin{array}{l}\text { Series }(4 \times) \text { (a list of } \\
\text { three or more items } \\
\text { arranged in parallel } \\
\text { form in a sentence) }\end{array}$ & $\begin{array}{l}\text { 1.... at further developing the } \\
\text { Orang Asli community to } \\
\text { become more dynamic, } \\
\text { independent and to play an } \\
\text { active role in society. }\end{array}$ & $\begin{array}{l}\text { In this example, series helps to } \\
\text { highlight the impact of the } \\
\text { government projects on the Orang } \\
\text { Asli's psyche, personality and outlook. }\end{array}$ \\
\hline $\begin{array}{l}\text { Testimonies }(4 \times)(a \\
\text { person's account or } \\
\text { view on a state of } \\
\text { being) }\end{array}$ & $\begin{array}{l}\text { 1. Ismail said when the } \\
\text { villagers previously took their } \\
\text { water woes to the } \\
\text { authorities... } \\
\text { 2. He said the only way for } \\
\text { them to have a better life was } \\
\text { to change their attitude and } \\
\text { lifestyle. }\end{array}$ & $\begin{array}{l}\text { Testimonies are spoken statements } \\
\text { that provide proof or evidence of a } \\
\text { phenomenon that is being described. } \\
\text { In this example, the testimonies drive } \\
\text { home the point that the Orang Asli } \\
\text { have to change their lifestyle if they } \\
\text { wish to improve their lot in life. }\end{array}$ \\
\hline $\begin{array}{l}\text { Dysphemism }(3 \times)(\text { the } \\
\text { use of vulgar or } \\
\text { disparaging terms) }\end{array}$ & $\begin{array}{l}\text { 1. Many of the village } \\
\text { inhabitants are hooked on } \\
\text { cheap liquor also known as } \\
\text { compounded hard liquor. } \\
\text { 2. Orang Asli folk set to gain } \\
\text { from JAKOA's assistance }\end{array}$ & $\begin{array}{l}\text { Dysphemisms are not neutral } \\
\text { expressions, they are offensive to both } \\
\text { the speaker and the hearer. These } \\
\text { words connote feelings of intense } \\
\text { dislike and abhorrence. In the first } \\
\text { example, "hooked on" shows that the } \\
\text { Orang Asli enjoy consuming alcohol } \\
\text { and that they cannot stop this negative } \\
\text { habit. }\end{array}$ \\
\hline
\end{tabular}

(Continued on next page)

Table 5. (Continued)

\begin{tabular}{lll}
\hline $\begin{array}{l}\text { Rhetorical structures } \\
\times \text { frequency }\end{array}$ & Examples from text & Explanation \\
\hline
\end{tabular}

In the second example, "folk" connotes simplicity and a life that 


\begin{tabular}{|c|c|c|}
\hline & & $\begin{array}{l}\text { adheres to traditional values and } \\
\text { practices. In using these words, the } \\
\text { Orang Asli's sensitivity is ignored. }\end{array}$ \\
\hline $\begin{array}{l}\text { Repetition }(5 \times) \text { (using } \\
\text { a word more than } \\
\text { once) }\end{array}$ & $\begin{array}{l}\text { 1. Many of the village } \\
\text { inhabitants are hooked on... } \\
\text { 2. ...they come in for the } \\
\text { cheap liquor instead... }\end{array}$ & $\begin{array}{l}\text { Words that are repeatedly used are } \\
\text { those that refer to alcohol and the } \\
\text { Orang Asli's drinking culture. }\end{array}$ \\
\hline $\begin{array}{l}\text { Understatement }(2 \times) \\
\text { (when a writer makes } \\
\text { a situation appear less } \\
\text { important) }\end{array}$ & $\begin{array}{l}\text { 1. While this may not seem } \\
\text { impressive when compared to } \\
\text { urban schools... }\end{array}$ & $\begin{array}{l}\text { Several achievements made by the } \\
\text { Orang Asli community have been } \\
\text { belittled in the news reports. One } \\
\text { instance is the depreciation of the } \\
\text { performance by a school attended } \\
\text { mostly by Orang Asli children. }\end{array}$ \\
\hline $\begin{array}{l}\text { Hyperbole }(5 \times) \text { the } \\
\text { use of exaggeration to } \\
\text { achieve a certain } \\
\text { effect) }\end{array}$ & $\begin{array}{l}\text { 1.... significant improvement } \\
\text { for the Orang Asli school that } \\
\text { was made possible by the } \\
\text { various initiatives } \\
\text { 2. ...the department had } \\
\text { solved more than } 300 \text { cases... }\end{array}$ & $\begin{array}{l}\text { Hyperbole is one of the most } \\
\text { frequently used features in the news } \\
\text { reports. Most of the time, its function } \\
\text { is to accentuate the positive effects of } \\
\text { the actions or projects undertaken by } \\
\text { the government agencies. In } \\
\text { embellishing a point, numerals are } \\
\text { often employed. }\end{array}$ \\
\hline
\end{tabular}

Tactical use of rhetorical items may contribute to the aesthetics, credibility and persuasive power of the news reports in highlighting certain ideas about the selfgroup and other-group members. Hyperbole is used to exaggerate the positive actions committed by the self-group members while positive acts by other-group members were disparaged through understatement. As shown in the above table, majority of the structures used in the news reports tend to project the Orang Asli community in an undesirable manner. Their achievements are demeaned and they are reported to be clinging to traditional ways to earn a living. The most destructive portrayal would be depicting them as alcoholics and no-gooders.

\section{Summary of Lexical, Syntactic and Rhetorical Analysis}

Based on the analysis, it is clear that lexical, syntactic and rhetorical structures are used to further reinforce certain stereotypes about the Orang Asli. These structures are also employed to help create a polarised world, one that favours the "self" rather than the "other". As Denis (1997) contends the media play a significant role in constructing a binary world, one that segregates the ordinary masses [as well as the hegemons or those in power] from the indigenous community and this notion has been proven to be true in the context of this research as well. 
Several ideas were obtained through the analysis of these linguistic aspects and these are presented as follows.

\section{Projection of the Orang Asli as being traditional}

Past studies (David, Ponmalar and Sri Kumar 2010; Denis 1997) have shown that the indigenous community tend to be stereotyped as people who still cling to their traditional lifestyle. In the same vein, similar depictions of the Orang Asli community as being dependant on the forest (through the use of simple present tense) and rejecting modernisation were clearly visible. These deprive them of opportunities to improve their lives (transmitted through testimonies, etc.). Such unsavoury projections facilitate the creation of a static social identity of the indigenous community as rightly pointed out by Wilson II and Gutierrez (1995) and Gergen (1985).

\section{Projection of political leaders and governmental officers as powerful and trustworthy}

Besides the projection of the Orang Asli, another visible pattern is the analysis of the verbal utterances of political leaders and government officers regarding the status and condition of the Orang Asli community. Ironically, readers learn about the community from these powerful people rather than from the Orang Asli community as voices of the latter (Orang Asli) are often muted. The Orang Asli may not share similar views or perspectives as these views are tainted, often filtered through the focalising consciousness of those in power. Sadly, it is these views that get circulated and reinforced by the media.

As seen in the analysis of syntactic structures, the "to clauses" are used to provide elaborations on the positive actions taken by the "self" or government agencies and simultaneously the negative perceptions of the "other" or the Orang Asli. In the same vein, rhetorical structures such as "series" highlight the impact of government projects in uplifting the morale of the community. Testimonies from government officials provide ample evidence on the improved lifestyle of the community. These personal statements from those in power accentuate the idea that the Orang Asli have to embrace modernity and change their lifestyle if they wish to improve their lives.

Projection of the Orang Asli community as responsible for their own pitiful state of living

In the analysis of lexical items, the news reports blame the community for their lack of advancement. For instance, they are censured for wanting to live in 
remote areas, for depending on the forest for their survival and for refusing to change their mentality and attitude. More importantly, they are disparaged for their alcohol addiction and their apathy towards their well-being. Reasons why they have turned to alcoholism as a form of escapism from harsh poverty are not discussed.

\section{Glorification of JAKOA and the other governmental agencies as the saviour of the Orang Asli community}

Besides highlighting the Orang Asli community, parties that get into the limelight when news about the community are being reported are the governmental organisations such as JAKOA, the Education Ministry, Rural and Regional Development Ministry, Public Works Department and the Perak National Registration Department. In almost all the news reports analysed, the mention of a governmental department or a governmental officer appeared almost obligatory. An abundance of lexical items are dedicated towards exalting their deeds. Examples of these include mentioning that "the state has not neglected them" and "programmes with good economic prospects".

\section{Analysis of Ideology}

According to van Dijk (1998), ideology creates the fundamental basis and the social reproduction of a particular group and may be reproduced through many different mediums such as text and talk. In analysing ideologies, one common trait which is normally constructed is the polarisation of the "self" versus the "other". Members of the "self" group tend to project themselves in a favourable way while diminishing the image of those who belong to the "other" group.

He further adds that in analysing the discursive polarisation of these two entities especially in news reports, features that need to be analysed are the thematic, lexical, syntactic and rhetorical structures. Through the analysis of the structures mentioned, the hidden ideology embedded in the texts may well be revealed and from there, a conclusion on the ideology of a particular group may be comprehended. 
One undeniable truth is the fact that the polarisation of the "self" versus the "other" is evident and very obvious in the news reports analysed. The Orang Asli community is depicted as traditional, dependent, as alcoholics and responsible for their own deplorable state of living. Neutral representation of the community does occur occasionally but it is minimal to the extent that it does not change the way the mainstream community perceives the Orang Asli community. In terms of lexical constructions, negative traits are usually attributed to the Orang Asli, who are the members of the "other" group. The use of rhetorical items helps to reinforce negative ideas about the community as well, such as by employing repetition to instil in the minds of the readers certain negative traits of the community.

In contrast, the "self" is elevated to a position where numerous positive actions committed by the group are mentioned in the text. Most of the time, they are placed in the position of the actor when they are reported to undertake positive acts. Such depictions project them as the ultimate saviours of the Orang Asli people who in contrast, appear weak and dependant. The polarisation pattern observed in this study concurs with previous research such as those by Dunn and Mahtani (2001) and Loh (2011).

\section{Conclusion}

As intimated in the introduction, less powerful nations are often silenced or muted in globalised space as they are conveyed to the world through a Westerncentric lens or perspective. As such, they are often portrayed as weak and powerless nations which help to sustain unequal power relations between Western powerful nations and less powerful ones in global space. Likewise, on the local front, the Orang Asli are also silenced, they are not granted space and agency to convey their views and thought processes, instead they are spoken about by others, especially those in power, the ones who own the media. Robbed of voice, they are often portrayed as weak and disempowered victims. The projection of the Orang Asli as primitive, dependent and as alcoholics is not strange or unfamiliar. Similar images and tropes of the indigenous community worldwide are being pedalled in global media, in books, films, comic strips and television. Such images have become so ingrained in our psyche and consciousness that they have formed part and parcel of our natural or common understanding of the indigenous community.

Findings of this study reveal that The Star, a mainstream daily, has reinforced prevailing stereotypes of the Orang Asli through the selected news reports, namely their semantic macrostructures and microstructures. Ideologically, the "self" group comprising the ruling elite and government agencies have been 
portrayed in a positive manner while the "other", the Orang Asli, in a negative way. To what extent does this represent the reality of this community's life? Are members of this community included in national dialogues especially on issues that concern their socio-economic development in particular the implementation of governmental projects, etc.? Are they allowed to influence decisions that are made about them?

Mainstream media play an important role as people tend to depend on this media to gather information and analysis of events on a day to day basis (McCausland 2004). Newspapers are expected to be objective and neutral in the way in which they report events, people and issues. However, as McCausland (2004, 84) argues, this may not be the case, as those who work in the media may have a biased or incorrect understanding of the historical and cultural experiences of the indigenous community. The inherent values of media practitioners help to influence the way in which news is "gathered, analysed and presented" to a local and global audience. In the same vein, the ruling elite and media conglomerates can also affect the ways in which news is manufactured for public consumption. These stakeholders are powerful as they can influence and shape minds and "the collective beliefs" of the citizens of a country through the former's selections of events and issues which are represented using certain discursive and linguistic strategies (McCausland 2004, 84). As the mediator of news, especially those that affect the life of marginal or minority groups, media practitioners have to report in a responsible manner, as the larger community may not have any direct access or knowledge of these minority communities.

The status of the Orang Asli as the sons of the soil is an undeniable fact. As such, they are entitled to enjoy the same treatment and privileges as the mainstream community. This study strongly advocates that all discriminatory portrayals of the community be discontinued and calls for an equal representation of the community in the media, especially The Star. More research focusing on media reports and media behaviour should be conducted in the future to address this issue.

\section{References}

Baharon Azhar Raffie'i. 1968. Religion and social change among the Orang Asli. Kuala Lumpur: Jabatan Hal Ehwal Orang Asli.

Bakhtin, M. 1981. The dialogic imagination. Austin, TX: University of Texas Press.

Biber, D. and Conrad, S. 2004. Corpus based comparison of registers. In Applying English grammar: Functional and corpus approaches, eds. Coffin, C., Hewings, A. and O'Holloran, K., 40-56. London: Arnold. 
Bowen, J. R. 2000. Should we have a universal concept of "indigenous peoples" rights?: Ethnicity and essentialism in the twenty-first century. Anthropology Today 16(4): 12-16, https://doi.org/10.1111/1467-8322.00037.

Brown, M. E., ed. 2003. Grave new world: Security challenges in the 21 st century. Washington: Georgetown University Press.

Carey, I. 1970. The religious problem among the Orang Asli. Journal of the Malayan Branch of the Royal Asiatic Society 43(1): 155-160.

Clifford, H. C. 1897. In court and kampong, being tales and sketches of native life in the Malay Peninsula. London: Grant Richards.

David, M. K., Ponmalar, A. and Sri Kumar, R. 2010. Representation of the Orang Asli community in the media. International Journal of Arts and Sciences 3(8): 90-107.

Denis, C. 1997. We are not you: First nations and Canadian modernity. Peterborough, ON: Broadview Press.

Dentan, R. K., Endicott, K., Gomes, A. G. and Hooker, M. B. 1997. Malaysia and the original peoples: A case study of the impact of development on indigenous peoples. Boston, USA: Allyn and Bacon.

Duncan, N. 1996. Discourses on public violence and the reproduction of racism. South African Journal of Psychology 26(3): 172-182, https://doi.org/10.1177/ 008124639602600307.

Dunn, K. and Mahtani, M. 2001. Media representation of ethnic minorities. Progress and Planning 55(3): 163-171.

Fairclough, N. 1995. Critical discourse analysis: The critical study of language. Harlow, UK: Longman.

Gergen, K. 1985. The social constructionist movement in modern psychology. American Psychologist 40: 266-275, https://doi.org/10.1037/0003-066X.40.3.266.

Goatly, A. 2000. Critical reading and writing: An introductory coursebook. London: Routledge.

Howell, S. 1995. The indigenous people of Peninsular Malaysia: It's now or too late. In Indigenous peoples of Asia, eds. Barnes, R. H, Gray, A. and Kingsbury, B., 273287. Ann Arbor, MI: Association for Asian Studies.

Inguanzo, I. 2011. Indigenous peoples, democracy and representation: The cases of Bolivia and Guatemala. Salamanca, Spain: Instituto De IberoAmerica, Universidad de Salamanca.

Loh, C. M. 2011. A study of comparison media coverage between mainstream news website The Star and alternative news website The Malaysian Insider on indigenous group issue in 2010. BComm diss., Universiti Tunku Abdul Rahman, Malaysia.

Lye, T. P. 2011. The wild and the tame in protected areas management, Peninsular Malaysia. In Beyond the sacred forest: Complicating conservation in Southeast Asia, ecologies for the 21 st century, eds. Dove, M. R., Sajise, P. E. and Doolittle, A. A., 37-61. Durham, NC: Duke University Press.

Maslin, C. 2002. The social construction of aboriginal peoples in the Saskatchewan print media. MA diss., University of Saskatchewan, Canada.

McCausland, R. 2004. Special treatment: The representation of aboriginal and Torres Strait islander people in the media. Journal of Indigenous Policy 4: 84-98.

Meadows, M. 2001. Voices in the wilderness: Images of aboriginal people in the Australian media. Westport, CT: Greenwood Press. 
Nicholas, C., Engi, J. and Teh, Y. P. 2000. The Orang Asli and the UNDRIP: From rhetoric to recognition. Subang Jaya, Selangor: Centre for Orang Asli Concerns.

Owen, D. 2003. Transnational mass media organizations and security. In Grave new world: Security challenges in the 21st century, ed. Brown, M. E., 233-258. Washington: Georgetown University Press.

Rachagan, S. S. 1990. Constitutional and statutory provisions governing the Orang Asli. In Tribal peoples and development in Southeast Asia, eds. Lim, T. G. and Gomes A., 101-111. Kuala Lumpur: University of Malaya.

Roseman, M. 1984. Malay and Orang Asli interactions: Views from legendary history. The Historiography of Southeast Asia. New York: Cornell University.

Sabihah Ibrahim. 1997. Hubungan etnik di kalangan Orang Asli: Satu kajian etnografi terhadap orang Temiar di Kampung Chengkelik, RPS Kuala Betis, Kelantan. BA diss., University of Malaya, Malaysia.

Schlesinger, P. 1998. Putting "reality" together. London: Routledge.

Stevens, G. 1998. "Racialised" discourses: Understanding perceptions of threat in postapartheid South Africa. South African Journal of Psychology 28(4): 204-214, https://doi.org/10.1177/008124639802800403.

Swettenham, F. A. 1880. Comparative vocabulary of the dialects of some of the wild tribes inhabiting the Malayan Peninsula, Borneo etc. Journal of the Straits Branch of the Royal Asiatic Society 5: 125-156.

Taylor, J. 2005. European indigenous Internet representation: Potentials and perils for Sámi. Finland: University of Lapland.

van Dijk, T. A. 2001. Discourse, ideology and context. Folia Linguistica 35(1-2): 11-40, https://doi.org/10.1515/flin.2001.35.1-2.11. 2000. New(s) racism: A discourse analytical approach. In Ethnic minorities and the media, ed. Cottle, S., 33-50, Buckingham: Open University Press. 1998. Ideology: A multidisciplinary approach. London: Sage. 1991. Racism and the press. London: Routledge. 1988. News as discourse. Hillsdale, NJ: Lawrence Erlbaum. 1980. Macrostructures. Hillsdale, NJ: Lawrence Erlbaum.

Wilson, C. C. II and Guiterrez, F. F. 1995. Race, multiculturalism and the media: From mass to class communication. 2nd ed. Thousand Oaks, CA: Sage.

Wray, L. 1903. The Malayan pottery of Perak. The Journal of the Anthropological Institute of Great Britain and Ireland 33: 24-35, https://doi.org/10.2307/2842987.

Zawawi Ibrahim. 1996. Kami bukan anti-pembangunan!: Bicara Orang Asli menuju Wawasan 2020. Petaling Jaya, Selangor: Persatuan Sains Sosial Malaysia. 